\title{
QTL Mapping linked to downy mildew resistance genes in maize (Zea mays)
}

\author{
MUH. DZULKIFLY ASHAN ${ }^{1, \vartheta}$, MIFTAHUDIN ${ }^{1}$, REFLINUR $^{2, \bullet »}$, MARCIA B. PABENDON ${ }^{3}$, \\ SIGIT BUDI SANTOSO ${ }^{3}$, AGUS SALIM ${ }^{4}$ \\ ${ }^{1}$ Multidisiplinary of Biotechnology Program, Institut Pertanian Bogor. Jl. Raya Dramaga, Kampus IPB Dramaga, Bogor 16680, West Java, Indonesia. \\ Tel./fax.: +62-821-22211530, `email: ashankifly@gmail.com \\ ${ }^{2}$ Indonesian Center for Agricultural Biotechnology and Genetic Resources Research and Development. Jl. Tentara Pelajar No. 3A, Bogor 16111, West \\ Java, Indonesia. Tel./fax.: +62-251-8338820, "vemail: reflinur@yahoo.com \\ ${ }^{3}$ Indonesian Cereals Research Institute. Jl. Dr. Ratulangi No. 274, Maros 90514, South Sulawesi, Indonesia \\ ${ }^{4}$ South East Sulawesi Assessment Institute for Agricultural Technology. Jl. Prof. Muh. Yamin No. 89, Kendari 93114, Southeast Sulawesi, Indonesia
}

Manuscript received: 4 April 2020. Revision accepted: 25 July 2020.

\begin{abstract}
Ashan MD, Miftahudin, Reflinur, Pabendon MB, Santoso SB, Salim A. 2020. QTL Mapping linked to downy mildew resistance genes in maize (Zea mays). Biodiversitas 21: 3735-3743. Downy Mildew (DM) caused by Peronosclerospora spp. is one of the most destructive diseases and problems in yield losses of maize production worldwide. Identification of molecular marker-linked to the DM resistance genes is considered as an important step in the improvement of the DM resistance nature in maize breeding program. The objective of the study was to identify molecular markers linked to the DM resistance genes in maize. A total of $198 \mathrm{~F}_{3}$ maize lines generated from a cross between R10-4430 and Kandora was used in microsatellite genetic map construction and the corresponding $\mathrm{F}_{3: 4}$ families were used in phenotypic evaluation to identify quantitative trait loci (QTLs) responsible for DM resistance-related trait. The entire genetic linkage map constructed with 28 SSR markers resulted in $460.3 \mathrm{cM}$ with an average distance between markers of 26.85 cM. Seven main-effect QTLs controlling the DM resistance genes were identified in the entire genome map of $F_{3}$ population with the phenotypic variation explained (PVE) values ranged from 43.35 to $53.71 \%$. Among detected QTLs, three QTLs, $q D M-P p 1 a, q D M-$ $P p 1 b_{1}$, and $q D M-P p 1 b_{2}$ were detected on chromosome 1 , one QTL, $q D M-P p 5$ was on chromosome 5, two QTLs, $q D M-P p 6 b_{1}$ and $q D M-$ $P p 6 b_{2}$ were on chromosome 6 and one QTL, $q D M-P p 10$ was on chromosome 10. The effect of detected QTLs responsible for DM resistance trait ranged from 43.35 to $53.71 \%$ and those will be potential to be further used as molecular aided selection in maize breeding for DM resistance.
\end{abstract}

Keywords: Disease resistance, downy mildew, maize, molecular markers

\section{INTRODUCTION}

Maize is one of the important carbohydrate-producing crops in the world, besides rice and wheat. Central American, South American, African, and Asian countries generally make maize as their staple food, especially Africa and some regions in Indonesia. Globally, maize production continues to rise along with increasing fulfillment of future maize needs. In Indonesian, during 2014 to 2018 maize production increased annually of which at $19,008,426$ ton, $19,612,435$ ton, $23,578,413$ ton, $28,924,015$ ton, and 30,253,938 ton, respectively (FAO 2020). However, Indonesian maize productivity is still relatively low. It is reported that in 2019, maize productivity in Indonesia was 5.33 tons/ha (FAO, 2020) and this productivity is lower in comparison with world's maize productivity. Some of the factors causing the low productivity of maize in Indonesia are the limited amount of maize germplasm, changing environmental conditions in each region, and the markers linked to less specific resistance genes, especially the downy mildew disease (DM). Downy Mildew is caused by the fungus Peronosclerospora which is one of the most important diseases in maize and can cause serious damage in crops throughout the world, especially in tropical Asia
(Rashid et al. 2018; Kim et al. 2020). Daryono et al. (2018) reported that the level of this pathogen attack reached \pm $90 \%$ in South of Sulawesi. As one of the maize production centers in Asia, therefore, Indonesia needs to be aware of such a disease. Generally, the spread of DM in Indonesia is caused by two species, such as Peronosclerospora maydis $(\mathrm{Pm})$ which is widely distributed in Java and Peronosclerospora philippinensis $(\mathrm{Pp})$ found in South Sulawesi (Muis et al. 2015). Some efforts to control this disease, such as regulating the period of land-free plantations, environmental sanitation and improvement of cropping patterns have not shown a significant suppression of maize yield loss. The use of resistant varieties is a very strategic approach in plant in controlling DM disease because it is more effective and relative safety for the environment. Advances in biotechnology, especially through the application of molecular markers as a selection tool for lines carrying the desired character can accelerate the plant breeding cycle with high accuracy (Gedil \& Menkir 2019).

The availability of molecular markers linked to DM disease resistance trait in maize is expected to shorten the time required to fix breeding lines which could not be resolved by conventional breeding. In addition, the main 
obstacle faced in the conventional selection process is the difficulty in choosing the right genes that are targeted for selection to be expressed in their morphological or agronomic traits (Ashkani et al. 2015). Therefore, the availability of molecular markers associated with desired traits would be benefit to overcome such a problem. The identification of quantitative trait loci (QTLs) responsible for the DM resistance genes in maize is still very limited. Several QTL mapping studies responsible for to the DM resistance in maize have been reported (Agrama et al. 1999; Azrai et al. 2015; Roberdi et al. 2010; Jampatong et al. 2013; Lohithaswa et al. 2015). Initial research conducted by Agrama et al. (1999) using $F_{2}$ families and RFLP markers of 109 pairs of markers representing 10 chromosomes of corn was able to explain the construction of the genetic map along $1648 \mathrm{cM}$. Three QTLs were detected as significant QTL on DM, two of them were mapped very close on chromosome 1 , while another one was on chromosome 9. The percentage of phenotypic variations explained (PVE) that could be explained against the degree of resistance to DM was $53.6 \%$. The identification of QTL activity was also carried out by Jampatong et al. (2013) using 760 pairs of SSR markers spread throughout the maize genome. Among these markers, as many as 195 pairs of markers are polymorphic. Based on the linkage analysis of these markers, nine QTLs were linked to downy mildew resistance gene, one QTL each on chromosomes 2, 3, 4 and 6, three QTL on chromosome 5 and two QTL on chromosome 9. The closest markers determine the location of the QTL mentioned above are umc1736 (chromosome 2), bngg1902 (chromosome 5), bng1867 (chromosome 6). Ruswandi et al. (2015) identified the locus of DM disease resistance on chromosome 6 with a $112 \mathrm{cM}$ position using the $\mathrm{BC}_{1} \mathrm{~F}_{2}$ population derived from a cross between P345 (resistant parent) and P23 (susceptible parent) which tested against the DM disease in the Philippines. Meanwhile, Jampatong et al. (2013) mention that a Simple Sequence Repeats (SSR) marker at chromosome 1, 2, 6, 7, and 10 related to the DM resistance using mapping population derived from Ki3 x CML139 crosses. Population differences (origin of parents) used in each genetic mapping activity usually produce molecular markers linked to desired traits with a specific population and those do not necessarily work if the markers are applied in populations with different genetic backgrounds.

In present study, identification of molecular markers associate with the DM resistance genes was carried out on a set of mapping populations generated from the maize germplasm collected in Indonesian Center Cereals Research Institute, Maros, South Sulawesi, Indonesia. The objective of this study was to identify QTL for the DM resistance gene in maize. It is expected that molecular markers associated with DM resistance characters derived from Indonesian maize population can be utilized in future maize breeding programs.

\section{MATERIALS AND METHODS}

\section{Genetic materials}

Genetic materials used in this study consisted of two sets of maize population $\left(\mathrm{F}_{3}\right.$ and $\left.\mathrm{F}_{3:}\right)$ consist of $198 \mathrm{~F}_{3}$ maize lines generated from a cross between R10-4430 (susceptible parent) and Kandora (resistant parent). The $\mathrm{F}_{3}$ and $F_{3: 4}$ populations, each along with their parental parents were used in genotypic and phenotypic analysis, respectively. to construct genetic map and the corresponding $\mathrm{F}_{3: 4}$ families subjected to the phenotypic evaluation. The female parent, R10-4430 was susceptible to DM with good agronomic performance, while the male as donor resistant to the DM. A set of maize SSR markers deposited on maize database (maizegdb.org) was applied on genotyping such population including two parental lines.

The research work was conducted in the Molecular Biology Laboratory of Indonesian Center for Agricultural Biotechnology and Genetic Resource Research and Development (ICABIOGRAD), Bogor, West Java, and in the research station of Indonesian Cereals Research Institute (ICERI) in Bonto Bili, Gowa, South Sulawesi, Indonesia.

\section{Segregation analysis of downy mildew in maize population $\mathrm{F}_{3:} 4$}

A total of 198 individual $\mathrm{F}_{3:} 4$ maize population including parental lines (R10-4430 and Kandora) were screened phenotypically for the DM resistance in the research station of Indonesian Cereals Research Institute (ICERI) in Bonto Bili, Gowa, South Sulawesi as one of the most endemic areas of the DM disease. The experiment was arranged in a randomized block design with three replications. Each individual $\mathrm{F}_{3:} 4$ plant of maize was planted in standard 4-m-long rows with 30 plants per row and plant to plant spacing of $70 \mathrm{~cm} \times 20 \mathrm{~cm}$. However, 5 out of 30 plants for each line were then removed at days after planting (DAP) from a row, so that only 25 plants were maintained for further observation. Susceptible maize genotypes (Anoman) were sown as spreader rows three weeks before planting entries or the test materials. Observation of the individual $\mathrm{F}_{3: 4}$ lines against the downy mildew disease was carried out for 5 times, including vegetative and generative phases of plants (14 DAP to 42 DAP).

\section{Analysis of leaf damage level}

Phenotypic analysis was carried out to observe the morphological expression of maize plants resistant to DM disease, especially that in the leaves. Each maize line was observed and the level of plant damage caused by the DM disease was compared with checked plants including both resistant and susceptible parents. Disease incidence was calculated according to the following formula recommended by Rashid et al. (2013):

Percentage of the DM incidence $=($ Number of plants infected per bed/Total number of plants per bed) $* 100$ 


\section{DNA isolation}

DNA isolation of $\mathrm{F}_{3}$ plant populations including the two parents was carried out based on DNA extraction method as described by Diyasree et al. (2014). Genomic DNA was isolated from healthy and young maize leaves (ages 21 to 28 DAP). Commonly, this method consisted of four main steps, such as destruction of maize leaf cell wall with cetyltrimethylammonium bromide (CTAB) extraction buffer, separation of solvent and dissolved solutions by centrifugation, DNA precipitation using isopropanol, $\mathrm{Na}$ acetate solution followed by incubation step at $-20^{\circ} \mathrm{C}$, and washing of DNA pellets with ethanol of $70 \%$. The quality and quantity of DNA were measured by both a nanodrop spectrophotometer (Thermo Scientific 2000) and agarose gel electrophoresis $1 \%$.

\section{Polymorphic marker survey}

A polymorphic marker survey was carried out on the two parents using a set of SSR markers spread across the chromosomes (275 markers) from maize genome database (maizegdb.org). Polymerase Chain Reaction (PCR) reaction was carried out in a total reaction volume of 12.5 $\mu \mathrm{L}$. Composition of the PCR reaction consisted of 10 $\mathrm{ng} / \mu \mathrm{L}$ maize DNA, $\mathrm{ddH}_{2} \mathrm{O}, 10 \mathrm{X}$ buffer PCR, $0.125 \mathrm{mM}$ dNTPs, $0.5 \mu \mathrm{M}$ primer, and 1 unit of Taq DNA polymerase enzyme. PCR amplification was carried out as many as 35 cycles with annealing temperature of each marker that previously optimized. Amplification was performed in a 96-well GeneAmp with the temperatures and times used for PCR were as follows: In the first cycle, the mixtures were pre-denatured at $95^{\circ} \mathrm{C}$ for $5 \mathrm{~min}$, and followed by 35 cycles of denaturation at $95^{\circ} \mathrm{C}$ for 30 seconds, annealing at each temperature optimation $\left({ }^{\circ} \mathrm{C}\right)$ for primer annealing, and primer extension at $72^{\circ} \mathrm{C}$ for 30 seconds. The final extension time for PCR amplification was $7 \mathrm{~min}$ at $72^{\circ} \mathrm{C}$ was programmed to allow for the completion of primer extension on a BioRad T-100 system (CA, USA). PCR products were separated using an $8 \%$ non denaturing polyacrylamide gel electrophoresis. A total of $3 \mu \mathrm{L}$ of PCR product mixed with loading dye was injected into the well of the polyacrylamide gel and then electrophoretically run in TBE 1X buffer at 80 Volts for 120 minutes. Gel was stained in an ethidium bromide solution and visualized using UV light through a Chemidoc (Biorad) machine. SSR markers that provided different sizes in both parents were recorded as polymorphic markers.

\section{Segregation analysis of molecular markers in $F_{3}$ population}

Banding patterns of $\mathrm{F}_{3}$ lines amplified by polymorphic SSR markers were scored as " $\mathrm{A}$ " if the allele size same with Kandora and "B" if it is same as R10-4430 allele types. While, if the lines showed both parent alleles type were scored as " $\mathrm{H}$ " or heterozygous allele. The scoring data was then arranged in an input file (using Microsoft Excel) which subjected as the genotypic data in the analysis of the association between molecular markers and the DM resistance trait.
Linkage map construction and association analysis of molecular markers with DM resistance trait

Construction of a linkage map between SSR markers was conducted using Mapmaker program version 3.0 with the like-hood of odds (LOD) value of 3 (Cui et al. 2016). A maximum distance was set up to 50 centiMorgan (cM) as a threshold to express the linkage among DNA markers and Kosambi function was used to convert recombinant values into genetic distances between these markers (Huehn 2011; Zhang et al. 2019). Linkage analysis between phenotypic and genotypic data was carried out by Composite Interval Mapping (CIM) method which implemented in the Windows QTLs Cartographer program version 2.5 (Wang et al. 2012). CIM analysis was used to perform joint analysis of data across environments to map QTLs and estimate their genetic effects (Wang et al. 2019). A series of two models were used in the analysis. Model 6, which is a standard model for CIM was used as control parameter, walk speed was set up to $2.0 \mathrm{cM}$, LOD value more than 3.0, and threshold value was set by 1000 permutation (significant level of 0.05) (Cui et al. 2016). The additive effect and phenotypic variation explained (PVE) of QTLs from environment were obtained under the assumptions of Model 3. Multiple regression analysis was performed to estimate the total proportion of phenotypic variation due to the additive effects $\left(\mathrm{R}^{2}\right)$ (Wang et al. 2012).

\section{RESULTS AND DISCUSSION}

\section{Downy mildew disease evaluation}

Appearance of DM disease resistance to maize was analyzed through leaf morphology changes at 14 to 42 HST (Figures 1.A-B). The frequency of DM disease was performed and grouped into five criteria: highly resistant (HR), resistant (R), moderate (M), susceptible (S), highly susceptible (HS) (Kim et al. 2016). Distribution of the 198 $\mathrm{F}_{3}$ populations against the DM disease varied greatly, of which a total $20,62,87,28$, and 1 maize lines were highly resistant, resistant, moderately, susceptible, and highly susceptible, respectively against the disease (Figure 1.C). Of them, a total of 62 plants $(31.3 \%)$ were attacked in the same range with the checked resistance varieties (disease incidence value of $>0 \%$ to $10 \%$ ), while 1 line $(0.5 \%)$ was attacked in the same range with checked susceptible varieties (disease incidence value of $>50 \%$ ), and the rest were in the same range with the second check varieties (tend to resistant). The average line value of DM disease resistance populations showed significant genotypic variability.

\section{Polymorphic SSR markers survey and $F_{3}$ lines segregation patterns}

Based on the polymorphic survey of SSR markers genotyped on the two parents, of the total 275 SSR marker, 108 SSR markers were identified as polymorphic markers. Figure 2 presented seven polymorphic primers produced in this study. The different band patterns between the two parents with $\mathrm{F}_{3}$ lines indicated that the markers used are polymorphic in selecting that lines during genotypic analysis. 


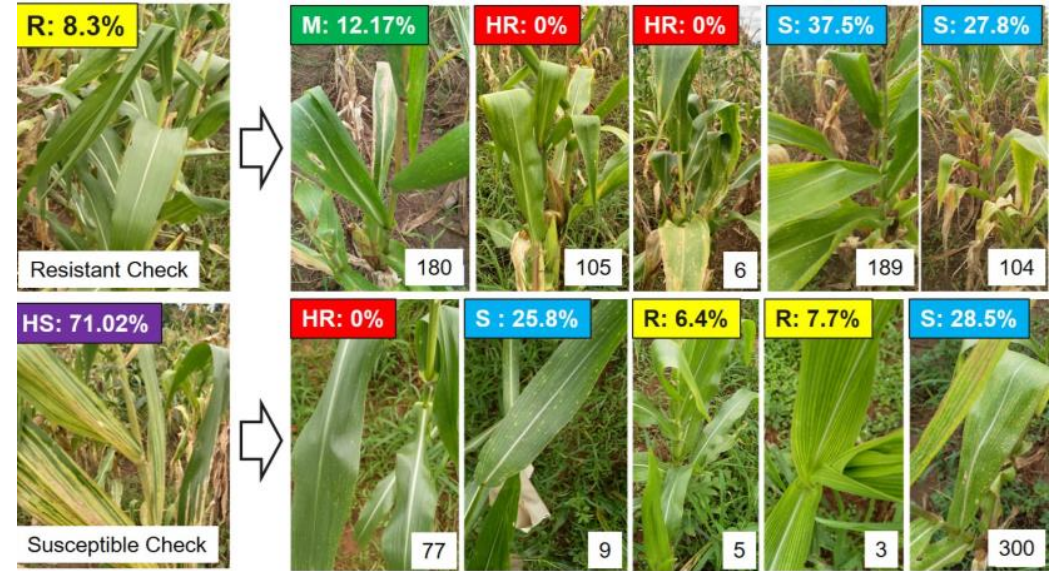

A

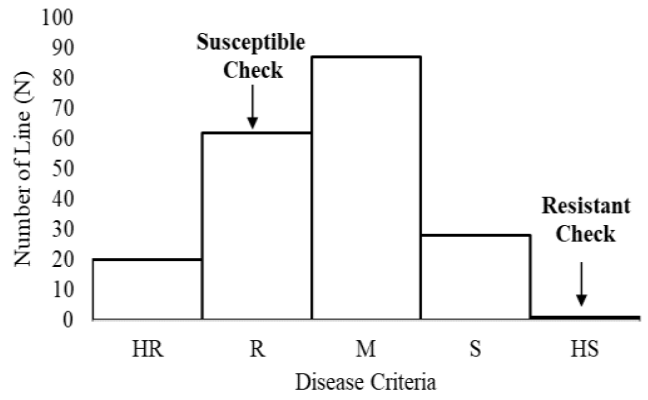

B

Figure 1. Phenotypic observation in the field. A. Performances of $F_{3: 4}$ maize population along with control plants under field trial for evaluation of DM resistance; B. Frequency distribution of DM disease reaction in $\mathrm{F}_{3: 4}$ populations.
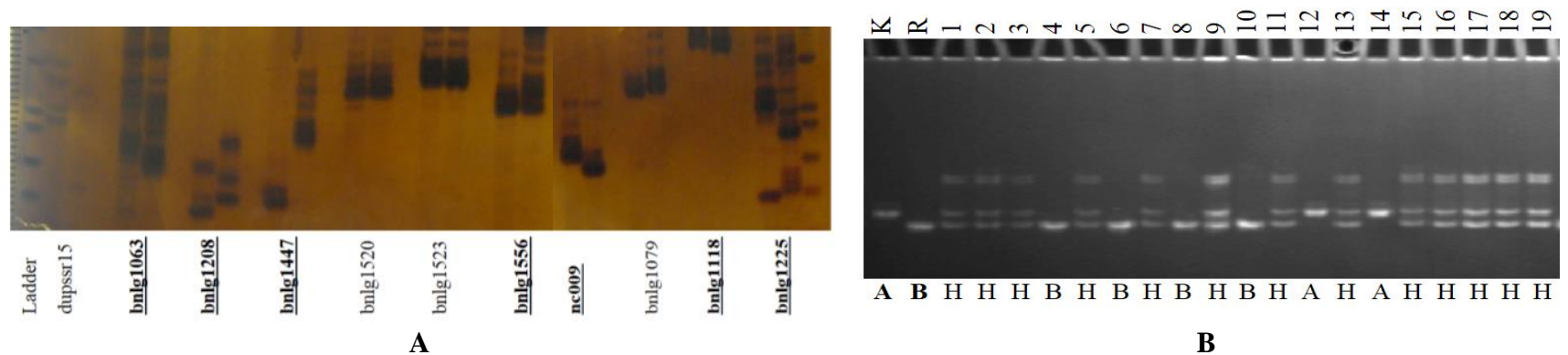

Figure 2. A. Polymorphic markers survey, and B. Segregation test of $F_{3}$ maize populations using nc009 polymorphic marker. K: Kandora male parent, R10: R10-440 female parent, 1-19: $\mathrm{F}_{3}$ maize populations (partially), A: male homozygous allele score, B: female homozygous score, and $\mathrm{H}$ : heterozygous allele score, Ld: Ladder $1 \mathrm{~Kb}^{\text {base }}{ }^{-1}$ size marker.

Segregation distortion was also examined in this study by looking at the deviation of the segregation ratio of a locus from the expected Mendelian ratio. Parental allele frequencies for all framework markers in both populations were calculated (Table 1), and used to assess the presence of distorted markers.

It can be inferred that genetic factors are responsible for segregation distortion if the markers are distorted in $\mathrm{F}_{3}$ population. A total of 20 markers were distorted in $F_{3}$ populations (Table 1). Of them, 6 markers were on chromosome 1 (umc2225, umc1685, bnlg109, bnlg1564, bnlg1884 and bnlg1556), two markers on chromosome 2 (bnlg1258 and bnlg1138), two markers on chromosome 4 (umc2279 and bnlg1241), two markers on chromosome 5 (phi048 and bnlg1118), three markers on chromosome 6 (nc010, bnlg1371 and bnlg1443), one marker on chromosome 8 (umc2042), two markers on chromosome 9 (bnlg1583 and bnlg128) and two markers on chromosome 10 (bnlg1655 and bnlg2190). Results showed severe segregation distortion in this population, seven markers were favoring the Kandora, one marker favoring the heterozygote, and 12 markers favoring the R10-4430 allele. The result indicated that genetic from R10-4430 had stronger effect than that from Kandora on transmission ratio distortion.

\section{Linkage map construction and QTL analysis}

The linkage map was constructed using $198 \quad \mathrm{~F}_{3}$ populations with 108 pairs of polymorphic SSR markers. Of these, only 44 out of 108 polymorphic markers were informative according to their segregation pattern in the $F_{3}$ maize population, one of which was nc009 marker shown in Figure 2. Genetic intervals between the markers obtained in the same chromosome on the basis of the recombination value with the Kosambi function were presented in Figure 3. Genetic linkage maps constructed from the $F_{3}$ maize population were successfully mapped 28 out of 44 polymorphic SSR markers at the significance of LOD value of 3.0 as a threshold. Overall, genetic linkage map resulted in present study was $460.3 \mathrm{cM}$ with an average distance between markers was $26.85 \mathrm{cM}$. A large genetic difference between the polymorphic markers was observed in present study and this phenomenon has commonly occurred in the construction of a genetic linkage map with low polymorphic markers available. In other words, molecular markers that showed unlinked to each other revealed a 
large distance between marker space (> $50 \mathrm{cM})$. In order to obtain a high-density linkage map, therefore, it is suggested that in future work more polymorphic markers between the two adjacent markers are needed to explore. The magnitude of the linkage map formed in this study was about $39.75 \%$ of the total maize genome in comparison to the maize genetic map reported by Kim et al. (2020).

\section{QTL analysis}

Based on the linkage analysis between genotype and phenotype data using the Windows QTL Cartographer ver. 2.5 program with the CIM analysis method, a total of seven QTLs were significantly linked to the DM resistance character. The seven QTLs were detected on four maize chromosomes, including chromosomes 1, 5, 6, and 10 . Three QTLs were located on chromosome 1 ( $q D M-P p l a$, $q D M-P p 1 b_{1}$, and $\left.q D M-P p 1 b_{2}\right)$, one QTL was on chromosome 5 ( $q D M-P p 5)$, two QTL were on chromosome $6\left(q D M-P p 6 b_{1}\right.$ and $\left.q D M-P p 6 b_{2}\right)$ and one QTL was on chromosome 10 (qDM-Pp10), and those with the peak position above the LOD value (3.0) (Figure 4). The information of flanking QTLs of the SSR markers, QTL positions, markers interval, LOD value, additive effects, and PVE were presented in Table 2.

Table 1. Chi-square test for segregation distortion of markers and genetic factors influencing distorted markers in $\mathrm{F}_{3}$ generated from Kandora and R10-4430

\begin{tabular}{|c|c|c|c|c|c|c|}
\hline \multirow{3}{*}{ Chr } & \multirow{3}{*}{ Marker } & \multicolumn{5}{|c|}{ (Kandora x R10-4430) } \\
\hline & & \multicolumn{3}{|c|}{ Genotype } & \multirow{2}{*}{$\begin{array}{c}\text { Chi- } \\
\text { square }\end{array}$} & \multirow{2}{*}{$\begin{array}{c}\text { Direction } \\
\text { of skew }\end{array}$} \\
\hline & & $\mathbf{K} / \mathbf{K}$ & $\mathbf{K} / \mathbf{R}$ & $\mathbf{R} / \mathbf{R}$ & & \\
\hline 1 & umc 2225 & 153 & 0 & 45 & $29.75^{* *}$ & Kandora \\
\hline 1 & umc1685 & 161 & 0 & 36 & $40.26^{* *}$ & Kandora \\
\hline 1 & bnlg109 & 159 & 0 & 39 & $36.73^{* *}$ & Kandora \\
\hline 1 & bnlg1564 & 73 & 0 & 124 & $6.70^{* * *}$ & R10-4430 \\
\hline 1 & bnlg1614 & 113 & 0 & 84 & $2.17^{\mathrm{ns}}$ & - \\
\hline 1 & bnlg1884 & 30 & 0 & 168 & $48.58^{* *}$ & R10-4430 \\
\hline 1 & bnlg1556 & 27 & 102 & 69 & $4.50^{*}$ & Heterozigot \\
\hline 2 & bnlg1225 & 43 & 88 & 66 & $1.36^{\mathrm{ns}}$ & - \\
\hline 2 & bnlg1258 & 73 & 0 & 124 & $6.70^{* *}$ & R10-4430 \\
\hline
\end{tabular}

\begin{tabular}{|c|c|c|c|c|c|}
\hline bnlg1138 & 144 & 7 & 47 & $24.00^{* *}$ & Kandora \\
\hline bnlg1246 & 59 & 50 & 86 & $1.92^{\mathrm{ns}}$ & - \\
\hline bnlg1035 & 87 & 10 & 101 & $0.50^{\mathrm{ns}}$ & - \\
\hline bnlg1447 & 39 & 98 & 61 & $1.23^{\mathrm{ns}}$ & - \\
\hline dupssr17 & 41 & 93 & 56 & $0.62^{\text {ns }}$ & - \\
\hline umc2281 & 21 & 163 & 14 & $0.12^{\text {ns }}$ & - \\
\hline umc1008 & 48 & 97 & 53 & $0.06^{\mathrm{ns}}$ & - \\
\hline umc2039 & 26 & 111 & 59 & $2.83^{\text {ns }}$ & - \\
\hline umc 2410 & 31 & 130 & 35 & $0.04^{\mathrm{ns}}$ & - \\
\hline umc 2279 & 86 & 64 & 47 & $3.92^{*}$ & Kandora \\
\hline bnlg1241 & 13 & 0 & 162 & $72.49^{* *}$ & R10-4430 \\
\hline phi048 & 31 & 4 & 162 & $44.22^{* *}$ & R10-4430 \\
\hline bnlg118 & 58 & 103 & 32 & $1.81^{\mathrm{ns}}$ & - \\
\hline bnlg1118 & 77 & 0 & 121 & $4.94^{*}$ & R10-4430 \\
\hline bnlg1759 & 59 & 90 & 46 & $0.44^{\mathrm{ns}}$ & - \\
\hline bnlg1740 & 47 & 110 & 40 & $0.13^{\text {ns }}$ & - \\
\hline nc010 & 28 & 0 & 170 & $51.43^{* *}$ & R10-4430 \\
\hline nc009 & 36 & 120 & 41 & $0.06^{\mathrm{ns}}$ & - \\
\hline bnlg1371 & 48 & 36 & 113 & $10.89^{* * *}$ & R10-4430 \\
\hline bnlg1443 & 40 & 5 & 153 & $32.57^{* *}$ & R10-4430 \\
\hline umc1401 & 46 & 108 & 43 & $0.02^{\mathrm{ns}}$ & - \\
\hline bnlg1200 & 56 & 85 & 48 & $0.18^{\text {ns }}$ & - \\
\hline umc2042 & 5 & 4 & 188 & $86.29^{* *}$ & R10-4430 \\
\hline bnlg1446 & 22 & 123 & 44 & $1.35^{\mathrm{ns}}$ & - \\
\hline bnlg1583 & 21 & 39 & 138 & $34.92^{* *}$ & R10-4430 \\
\hline umc 2337 & 45 & 123 & 28 & $0.75^{\mathrm{ns}}$ & - \\
\hline umc1037 & 25 & 134 & 37 & $0.37^{\mathrm{ns}}$ & - \\
\hline phi028 & 32 & 120 & 41 & $0.22^{\mathrm{ns}}$ & - \\
\hline bnlg128 & 68 & 76 & 30 & $4.77^{*}$ & Kandora \\
\hline bnlg1209 & 49 & 80 & 59 & $0.28^{\mathrm{ns}}$ & - \\
\hline bnlg1525 & 49 & 101 & 48 & $0.00^{\mathrm{ns}}$ & - \\
\hline bnlg1655 & 194 & 0 & 4 & $92.08^{* *}$ & Kandora \\
\hline bnlg2190 & 73 & 2 & 123 & $6.38 *$ & R10-4430 \\
\hline bnlg1028 & 38 & 101 & 58 & $1.03^{\mathrm{ns}}$ & - \\
\hline phi118 & 36 & 99 & 46 & $0.31^{\mathrm{ns}}$ & - \\
\hline
\end{tabular}

Note: Chr.: Chromosome, Marker: Significant SSR marker (Mapmaker), Genotype K/K: The number of alleles that follow the Kandora (Resistant allele for DM), K/R: The number of alleles that follow heterozygous allele, R/R: The number of alleles that follow the R104430 (Susceptible allele for DM), Chi-square: A chi-square: a test that measures how expectations compare to actual observed data, Direction of Skewed: a measure of the asymmetry of the probability distribution of 198 maize lines $\left(\mathrm{F}_{3: 4)}\right.$.

Table 2. QTLs for the Downy Mildew (DM) resistance identified in the $\mathrm{F}_{3}$ maize population generated from Kandora and R10-4430 cross

\begin{tabular}{|c|c|c|c|c|c|c|c|c|c|c|c|}
\hline Chr. & QTL & Flanking marker (bin) & $\begin{array}{c}\text { QTL } \\
\text { Position }\end{array}$ & $\begin{array}{c}\text { Interval } \\
\text { Marker } \\
\text { (cM) }\end{array}$ & LOD & $\begin{array}{c}\text { Additive } \\
\text { effect }\end{array}$ & $\mathbf{a}$ & d & $\begin{array}{c}\text { Gene } \\
\text { action }\end{array}$ & $\begin{array}{c}\text { PVE } \\
(\%)\end{array}$ & $\begin{array}{c}\text { Favorable } \\
\text { allele }\end{array}$ \\
\hline $1 \mathrm{a}$ & $q D M-P p l a$ & umc2225 (1.01) - umc1685 (1.01) & 6.01 & $0.0-23.4$ & 3.13 & 1.33 & 1.33 & 22.64 & OD & 47.74 & Kandora \\
\hline $1 \mathrm{~b}$ & $q D M-P p 1 b 1$ & bnlg1564 (1.07) - bnlg1884 (1.05) & 4.01 & $0.0-38.7$ & 6.85 & -0.89 & -0.89 & 23.67 & OD & 45.7 & R10-4430 \\
\hline $1 b$ & $q D M-P p 1 b 2$ & bnlg1564 (1.07) - bnlg1884 (1.05) & 36.01 & $0.0-38.7$ & 6.7 & 0.81 & 0.81 & 24.43 & OD & 43.35 & Kandora \\
\hline 5 & $q D M-P p 5$ & phi048 (5.07) - bnlg1118 (5.07) & 6.01 & $0.0-38.0$ & 4.69 & 0.2 & 0.20 & 20.61 & OD & 51.12 & Kandora \\
\hline $6 b$ & $q D M-P p 6 b 1$ & nc010 (6.04) - bnlg1371 (6.02) & 4.01 & $0.0-31.2$ & 7.49 & 0.87 & 0.87 & 22.70 & OD & 47.73 & Kandora \\
\hline $6 b$ & $q D M-P p 6 b 2$ & bnlg1371 (6.02) - bnlg1443 (6.05) & 77.21 & $31.2-84.6$ & 7.12 & -0.55 & -0.55 & 20.87 & OD & 53.71 & R10-4430 \\
\hline 10 & $q D M-P p 10$ & bnlg2190 (10.06) - bnlg1028 (10.06) & 6.01 & $0.0-44.2$ & 5.22 & -0.78 & -0.78 & 20.84 & OD & 50.68 & $\mathrm{R} 10-4430$ \\
\hline
\end{tabular}

Note: Chr.: Chromosome, qDM-Pp: QTL Downy Mildew Peronosclerospora philippinensis, marker that was provided underlines is the closest marker to the QTL position, Marker intervals: the distance between markers in centimorgan units (cM), a: additive effect (a), d: Dominance effect (d), PVE (Phenotypic Variation Explained) is phenotypic variations presentation (\%) of the total value of additive effects and dominant effect for putative QTL (model 3), Additive effect: positive value indicates the contribution of the donor alleles (Kandora) to the $\mathrm{F}_{3}$ population to increase DM disease resistance 


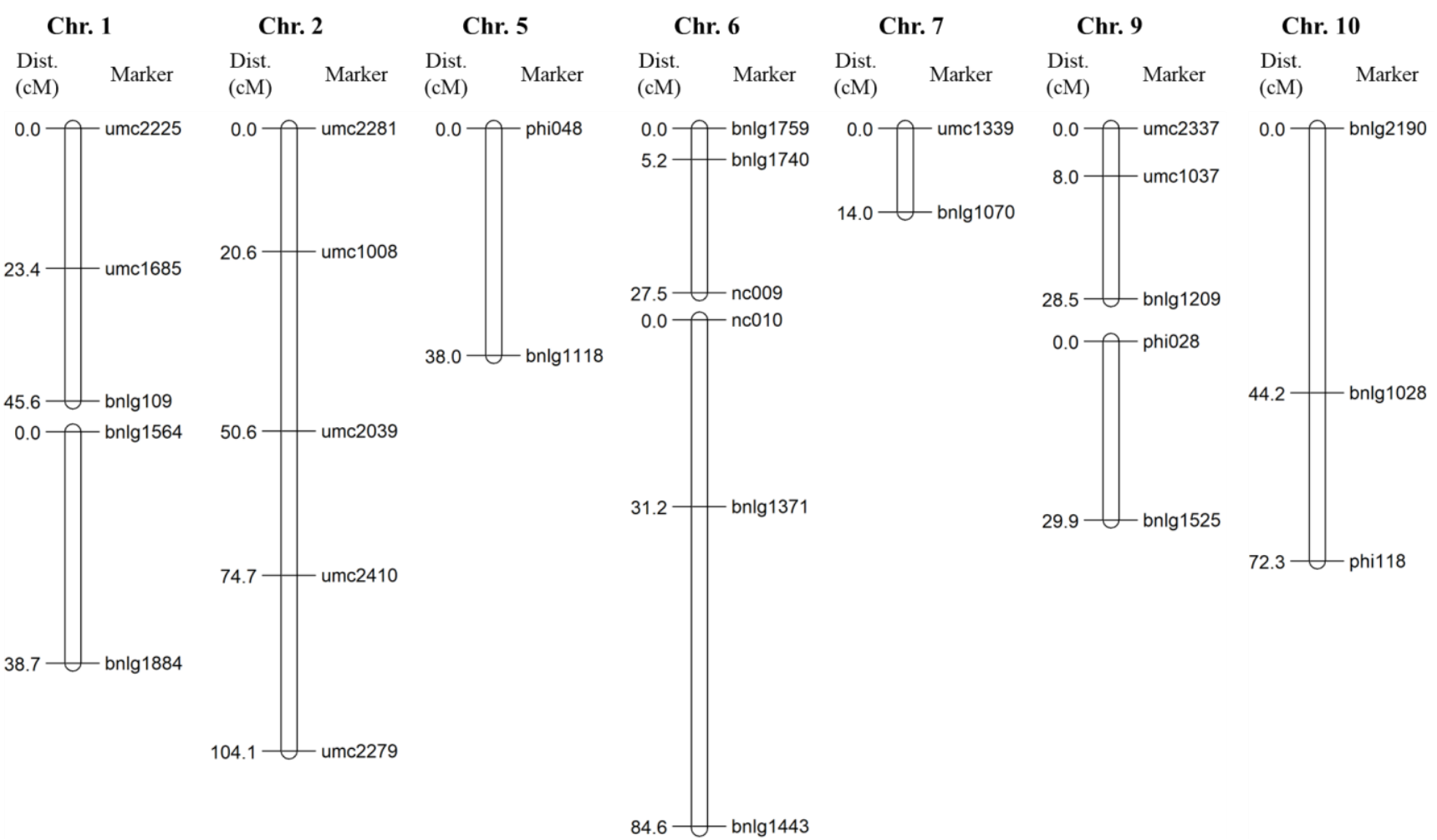

Figure 3. Linkage map of SSR markers constructed in present study. Intervals between the marker (cM) are linked to each chromosome (Chr.-n)

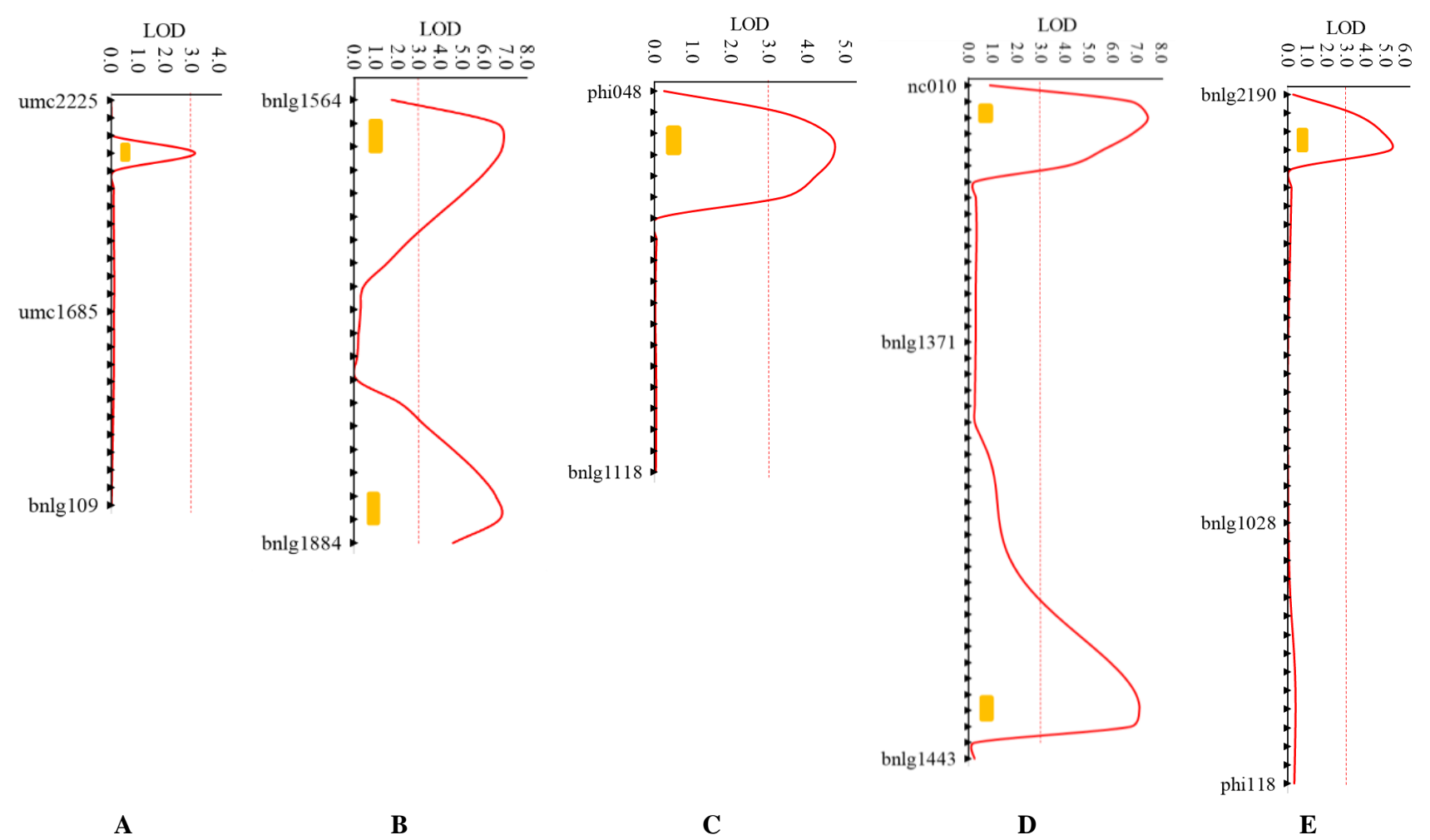

Figure 4. QTL position to DM resistance character of $\mathrm{F}_{3}$ populations. A. Chromosome 1a; B. Chromosome 1b; C. Chromosome 5; D. Chromosome 6b; E. Chromosome 10. qDM-Pp: QTL Downy Mildew Peronosclerospora philippinensis, LOD: Likelihood of odds, cM: centi Morgan 
With regards to the QTL positions to the DM trait ranged from $4.01 \mathrm{cM}\left(q D M-P p 1 b_{1}\right.$ and $\left.q D M-P p 6 b_{1}\right)$ to $77.21\left(q D M-P p 6 b_{2}\right)$. Based on the closest QTL position to the DM resistance character, $q D M-P p l b_{1}$ was flanked by bnlg1564 and bnlg1884 markers along chromosome 1and $q D M-P p 6 b_{1}$, was flanked by nc010 and bnlg1371 markers along chromosome 6. Of these, the bnlg1564 and nc010 markers were the closest marker to the QTL $q D M-P p 1 b_{1}$ and $q D M-P p 6 b_{1}$ peaks, respectively. Based on gene action observed in present study, each parental lines provided an additive effect on the QTL responsible to the DM disease. In $q D M-P p 1 b_{1}, q D M-P p 6 b_{2}$, and $q D M-P p 10$, the additive effect (it) came from R10-4430 (susceptible) parent while the other QTL came from Kandora (resistant) parent. Overdominance effect was observed for increasing the DM at all QTL loci was derived from Kandora parent. The effect of QTL found in present study showed a large effect on phenotype reflected by a high value of phenotypic variation explained (PVE), value ranged from $43.35 \%$ to $53.71 \%$ Table 2). Kandora allele contributed to an increase in DM resistance at four putative QTLs designated as $q D M-P p l a$, $q D M-P p 1 b 2, q D M-P p 5$, and $q D M-P p 6 b 1$ loci on chromosome 1, 2, 5 and 6.

\section{Discussion}

To reduce DM infection in maize crops have been performed various attempts such as lines screening, chemical application, and management pattern cultivation. It, however, still provided negative impact on production losses and genetic variability on the pathogen's adaptability. Roberdi et al. (2010) explained that the distribution factor of resistance character was very dependent on the genetic variability level, phenotypic variability, and interaction between genetic and environment. The formation of resistant varieties was important to be developed, considering that in nature the maize parents have not been found to encode the downy resistance character. Based on phenotypic characterization of the $198 \mathrm{~F}_{3: 4}$ maize population resulted in 20 maize lines were highly resistance (HR), 62 lines were resistant (R), 87 lines were moderately resistance (MR), 28 lines were susceptible (S) and 1 line was higly susceptible (HS) against the DM disease. Of these, 62 plants $(31.3 \%)$ were attacked in the same range as resistant varieties (>0 to 10 $\%)$. The distribution of HR plants showed that DM resistance response from donor parents has been introgressed into their progenies, so that it needed for relatively more homogeneous population studies (Roberdi et al. 2010; Boddy 2015)

Molecular marker, one of new technology in biotechnology, was a selection tool for lines possessing the desired character, so that, it can accelerate the plant breeding cycle with high accuracy (Kordrostami and Rahimi 2015). The availability of molecular markers linked to DM disease resistance trait in maize plants will potentially benefit to cut the conventional breeding cycle which requires a relatively long time (Jiang 2013). Based on the polymorphic survey of 275 SSR markers pairs on the two parents, 108 SSR primers showed polymorphically.
Of them, a total of 44 pairs of markers were informatively segregated in the $198 \mathrm{~F}_{3}$ maize lines, while the rest of the primers did not provide banding patterns suggesting that more markers are needed to apply in order to identify precise loci associated with target genes. Therefore, the availability of a set of polymorphic markers dispersed evenly along all the maize chromosomes, population type and total population would give high opportunity in identifying molecular markers associated with DM resistance trait (Ferreira et al. 2006). Regardless of population size, most published experiments with replicated trials have used between 100 and 200 progenies in QTLs study (Semagn et al. 2010). Recent QTLs study related to the downy mildew resistance genes conducted by Lohithaswa et al. (2015) used a total of 185 lines of sorghum $\mathrm{F}_{2}$ population, Ruswandi et al. (2015) have also succeeded to identify QTLs responsible to DM resistance using 142 maize BC1F1 lines. Therefore, in present study, a population size contained 198 maize lines is comparable with that in previous study to detection of QTLs with large phenotypic effect.

In present study, of the ten chromosomes in maize genome, the SSR markers could only be mapped in seven chromosomes based on genotyping analysis on the $F_{3}$ maize population. The SSR markers were not successfully constructed on chromosomes 2, 3, and 8 in present study due to they were not linked to each other. It can be caused by the large distance between polymorphic markers might be the reason for such unlinked markers observed in current study. Among the linked SSR markers constructed in present study, those on chromosome 6 showed a high number of SSR markers that could be mapped (six pairs of markers). Linkage map constructed on chromosomes 1, 6, and 9 each was divided into two maps, namely chromosomes 1a and $1 \mathrm{~b}$ (chromosome 1), chromosomes $6 \mathrm{a}$ and $6 \mathrm{~b}$ (chromosome 6), and chromosome $9 \mathrm{a}$ and $9 \mathrm{~b}$ (chromosome 9), respectively. The separation of the linkage maps was caused by the recombination value of each marker in the different chromosomes from each other with the position of the nearest marker was sorted based on the maximum distance (maximum-likelihood) between the markers in one chromosome and breakpoints segment more than $50 \mathrm{cM}$ (Portwood et al. 2019). These results showed similar events with those reported by Sabry et al. (2006), in which found 89 polymorphic SSR markers constructed in their study showed higher map distances (exceeding 60 $\mathrm{cM}$ ) with adjacent markers in the linkage group, significantly expanding genetic map distance. This phenomenon occurred due to the unavailability of the polymorphic SSR locus at bin location 6.01-6.04, making chromosome 6 was divided into two sub-groups, called as $6 \mathrm{~A}$ and $6 \mathrm{~B}$. The final map produced using 80 SSR markers has 11 linking groups. Through segregation analysis, DNA marker sequence and the relative distance between these markers can be determined. The value of recombination frequency between two markers that get smaller shows the closeness of the location of the two markers in a chromosome. Conversely, the higher the frequency of recombination between two markers, the farther the 
distance between them on a chromosome. A marker or gene is said to be linked if it has a recombination frequency value of less than $50 \%$ (Hartl 1988).

The linkage between phenotypic and genotypic data obtained seven QTL that was spread on four maize chromosomes (1, 5, 6, and 10). $q D M-P p l b_{1}$ was flanked by bnlg1564 and bnlg1884 markers on chromosome 1 and $q D M-P p 6 b_{1}$, was flanked by nc010 and bnlg1371 markers on chromosome 6 . Of these, the bnlg1564 and nc010 markers were the closest marker to the QTL $q D M-P p 1 b_{1}$ and $q D M-P p 6 b_{1}$ peaks, respectively. Based on gene action observed in present study, each parental line provided an additive effect on the QTL responsible to the DM disease. In $q D M-P p 1 b_{1}, q D M-P p 6 b_{2}$, and $q D M-P p 10$, the additive effect (it) came from R10-4430 (susceptible) parent while the other QTL came from Kandora (resistant) parent. The contribution of donor parent alleles inherited to their progenies can be known from the additive effect value in which three QTL was influenced by the allele R10-4430 (susceptible) while the other QTL was dominated by Kandora (resistant) parents allele. De Almeida et al. (2016) reported that additive effect was closely related to the contribution of donor alleles that were polygenically inherited to certain resistance characters. PVE values for all QTLs were expressed as major gene effects, whereas minor gene effects are stated when PVE values more than $10 \%$ (Nagabhusan et al. 2014). Mechanism of the effects of the major or minor genes can be seen from the number of plants successfully infected by pathogens that cause DM (Li et al. 2011; Sukhwinder-Singh et al. 2012; Shah et al. 2017). The PVE diversity in the linkage area was caused by infection pathogenic factor to the response of the resistance maize lines. Based on previous study, Kim et al. (2017) and Ruswandi et al. (2015) have identified QTL for downy resistance on chromosome 1 using $\mathrm{F}_{2}$ and $\mathrm{BC}_{1} \mathrm{~F}_{2}$ populations, respectively. Furthermore, it was also reported by Jampatong et al. (2013) that QTL related to Pp in the RILs, Lohithaswa et al. (2015) found QTL related to Ps (Peronosclerospora sorghi) in $\mathrm{F}_{2}$ population, and QTL linked $\mathrm{Ph}$ (Peronosclerospora heteropogoni) character was obtained $\mathrm{BC}_{1} \mathrm{~F}_{2}$ population (Kim et al. 2020). Based on this study, we conclude that response of $198 \mathrm{~F}_{3: 4}$ lines on the DM disease in the field varied from highly resistance to highly succeptible and the DM resistance related QTLs found in present study would give new insight on the future molecular maize breeding program for resistant against downy mildew disease.

\section{ACKNOWLEDGEMENTS}

This study was funded by the Research, Study, and Strategic Agricultural Development Cooperation (KP4S) program year 2018 under Indonesian Agency for Agricultural Research and Development, Ministry of Agriculture. The authors wish to thank the head of Indonesian Center for Agricultural Biotechnology and Genetic Resources Research and Development (ICABIOGRAD) for providing laboratory facilities for molecular work activities and head of the Indonesian
Cereals Research Institute (ICRI) who facilitated field experiment, and in particular, we would like to extend our gratitude to Haryati and Dita who have assisted us in phenotyping activities in the field.

\section{REFERENCES}

Ashkani S, Rafii MY, Shabanimofrad M, Miah G, Sahebi M, Azizi P, Tanweer FA, Akhtar MS, Nasehi A. 2015. Molecular breeding strategy and challenges towards improvement of blast disease resistance in rice crops. Front Plant Sci 6 (11): 1-14. 10.3389/fpls.2015.00886

Boddy CR. 2015. Sample size for Qualitative Interviews. Qual Mark Res Int J 19: 426-432.

Cui F, Fan X, Chen M, Zhang N, Zhao C, Zhang W, Han J, Ji J, Zhao X, Yang L, Zhao Z, Tong Y, Wang T, Li J. 2016. QTL detection for wheat kernel size and quality and the responses of these traits to low nitrogen stress. Theor Appl Genet 129 (3): 469-484.

Daryono BS, Parazulfa A, Purnomo P. 2018. Uji ketahanan tujuh kultivar jagung (Zea mays L.) terhadap penyakit bulai (Peronosclerospora spp.). Biog. J Ilmu Biol 6 (1): 11-17. [Indonesian]

De Almeida JE, Guimarães JFR, Silva FFE, De Resende MDV, Muñoz P, Kirst M, Resende MFR. 2016. The contribution of dominance to phenotype prediction in a pine breeding and simulated population. Heredity (Edinb) 117 (1): 33-41.

Diyasree P, Lokesh KA, Lidiya John P, Joy T, Teena Ramachandran V, Muttakulath AT, Manila TM, Sandhya Rajan VTK, Mathew D. 2014. A simplified protocol for the recovery of high-quality DNA from nutmeg. J Trop Agric 52 (1): 79-85.

FAO. 2020. Maize Production. Food and Agriculture Organization, United Nations, Rome, Italy.

Ferreira A, da Silva MF, da Costa e Silva L, Cruz CD. 2006. Estimating the effects of population size and type on the accuracy of genetic maps. Genet Mol Biol 29 (1): 187-192.

Gedil M, Menkir A. 2019. An integrated molecular and conventional breeding scheme for enhancing genetic gain in Maize in Africa. Front Plant Sci 10 (1430): 1-17.

Gutierrez-Gonzalez JJ, Mascher M, Poland J, Muehlbauer GJ. 2019. Dense genotyping-by-sequencing linkage maps of two Synthetic W7984×Opata reference populations provide insights into wheat structural diversity. Sci Rep 9: 1793. DOI: 10.1038/s41598-01838111-3.

Huehn M. 2011. On the bias of recombination fractions, Kosambis and Haldanes distance based on frequencies of gametes. Genome 54 (3): 196-201.

Jampatong C, Jampatong S, Jompuk C, Sreewongchai T, Grudloyma P, Balla C, Prodmatee N. 2013. Mapping of QTL affecting resistance against sorghum downy mildew (Peronosclerospora sorghi) in maize (Zea mays L). Maydica 58 (2): 119-126.

Jiang G-L. 2013. Molecular Markers and Marker-Assisted Breeding in Plants. Plant Breeding from Laboratory to Fields. IntechOpen, UK.

Kim HC, Kim KH, Song K, Kim JY, Lee BM. 2020. Identification and validation of candidate genes conferring resistance to downy mildew in maize (Zea mays L.). Genes (Basel) 11 (2): 191. DOI: 10.3390/genes11020191

Kim JY, Moon J-C, Kim HC, Shin S, Song K, Kim K-H, Lee B-M. 2017. Identification of downy mildew resistance gene candidates by positional cloning in maize (Zea mays subsp. mays; Poaceae). Appl Plant Sci 5 (2): 1600132. DOI: 10.3732/apps.1600132

Kim K, Moon J, Kim JY, Kim HC, Shin S, Song K. 2016. Evaluation of maize downy mildew using spreader row technique. Korean J Crop Sci 61 (1): 41-49.

Kordrostami M, Rahimi M. 2015. Molecular markers in plants: Concepts and applications. Genet Third Millenn 13 (2): 4024-4031.

Li WH, Liu W, Liu L, You MS, Liu GT, Li BY. 2011. QTL mapping for Wheat flour color with additive, epistatic, and QTLxenvironmental interaction effects. Agric Sci China 10 (5): 651-660.

Lohithaswa HC, Jyothi K, Sunil KKR, Puttaramanaik, Hittalmani S. 2015. Identification and introgression of QTLs implicated in resistance to sorghum downy mildew (Peronosclerospora sorghi (Weston and Uppal) C.G. Shaw) in maize through marker-assisted selection. J Genet 94 (4): 741-748. 
Muis A, Nonci N, Pabendon MB. 2015. Skrining ketahanan galur S1 Jagung terhadap penyakit bulai dan pembentukan galur S2 tahan penyakit bulai. Bul Plasma Nutfah 21 (1): 17-24. [Indonesian]

Nagabhusan, Lohithaswa HC, Sreeramasetty TA, Puttaramanaik, Hittalmani S. 2014. Identification of stable source of resistance to sorghum downy mildew in maize (Zea mays L.). J Agroecol Nat Resour Manag 1 (3): 176-178.

Portwood JL, Woodhouse MR, Cannon EK, Gardiner JM, Harper LC, Schaeffer ML, Walsh JR, Sen TZ, Cho KT, Schott DA, Braun BL, Dietze M, Dunfee B, Elsik CG, Manchanda N, Coe E, Sachs M, Stinard P, Tolbert J, Zimmerman S, Andorf CM. 2019. Maizegdb 2018: The maize multi-genome genetics and genomics database. Nucleic Acids Res 47 (D1): D1146-D1154.

Qu P, Shi J, Chen T, Chen K, Shen C, Wang J, Zhao X, Ye G, Xu J, Zhang L. 2020. Construction and integration of genetic linkage maps from three multi-parent advanced generation inter-cross populations in rice. Rice 13 (1): 1-16. DOI: 10.1186/s12284-020-0373-Z

Rashid Z, Singh PK, Vemuri H, Zaidi PH, Prasanna BM, Nair SK. 2018 Genome-wide association study in Asia-adapted tropical maize reveals novel and explored genomic regions for sorghum downy mildew resistance. Sci Rep 8 (1): 1-12. DOI: 10.1038/s41598-01718690-3

Rashid Z, Zaidi PH, Vinayan MT, Sharma SS, Srirama Setty TA. 2013. Downy mildew resistance in maize (Zea mays L.) across Peronosclerospora species in lowland tropical Asia. Crop Prot 43 183-191.

Roberdi, Aswidinnoor H, Setiawan A, Sutrisno, Pabendon MB, Azrai M. 2010. Keterpautan 23 marka mikrosatelit pada kromosom 6 dan 7 dengan karakter ketahanan populasi jagung terhadap penyakit bulai (Peronosclerospora maydis). J AgroBiogen 6 (1): 10-17. [Indonesian]
Ruswandi D, Hautea DM, Carpena AL, Lantican RM, Salazar AM, Raymundo AD. 2015. Quantitative trait loci mapping of Philippine downy mildew resistance gene in maize (Zea mays L.). Zuriat 13 (1): 27-34.

Sabry A, Jeffers D, Vasal SK, Frederiksen R, Magill C. 2006. A region of maize chromosome 2 affects response to downy mildew pathogens. Theor Appl Genet 113 (2): 321-330.

Semagn K, Bjørnstad $\AA$, Xu Y. 2010. The genetic dissection of quantitative traits in crops. Electr J Biotechnol 13 (5): 1-45.

Shah L, Si H, Wang S, Zhu Y, Jiang H, Cao J, Ali A, Ma C. 2017. Quantitative trait loci associated to Fusarium head blight resistance in wheat populations containing Annong-1124 and Zhoumai-27. Physiol Mol Plant Pathol 100: 67-74.

Sukhwinder-Singh, Hernandez M V., Crossa J, Singh PK, Bains NS, Singh K, Sharma I. 2012. Multi-trait and multi-environment QTL analyses for resistance to wheat diseases. PLoS One 7 (6): e38008. DOI: $10.1371 /$ journal.pone.0038008.

Wang L, Cheng Y, Ma Q, Mu Y, Huang Z, Xia Q, Zhang G, Nian H. 2019. QTL fine-mapping of soybean (Glycine max L.) leaf type associated traits in two RILs populations. BMC Genomics 20: 260. DOI: $10.1186 / \mathrm{s} 12864-019-5610-8$.

Wang S, Basten CJ, Zeng Z-B. 2012. Windows QTL Cartographer 2.5, Department of Statistics, North Carolina State University, Raleigh, $\mathrm{NC}$

Zhang C, Li L, Liu Q, Gu L, Huang J, Wei H, Wang H, Yu S. 2019. Identification of loci and candidate genes responsible for fiber length in upland cotton (Gossypium hirsutum L.) via association mapping and linkage analyses. Front Plant Sci 10: 53. DOI: 10.3389/fpls.2019.00053. 